\title{
Unrelated Transplants for High-risk Adult Acute Lymphoblastic Leukaemia
}

\author{
Christelle Ferrà ${ }^{1}$ and Josep-Maria Ribera ${ }^{2}$ \\ 1. Attending Physician; 2. Chief, Haematology Department, Catalan Institute of Oncology, University Hospital Germans Trias i Pujol
}

DOI: 10.17925/EOH.2009.03.1.45

\begin{abstract}
Standard chemotherapy has a poor outcome in adult patients with high-risk acute lymphoblastic leukaemia (ALL). Allogeneic haematopoietic stem cell transplant (allOSCT) is the treatment of choice, and SCT with alternative progenitors should be considered in the absence of a matched sibling donor. There is great heterogeneity in the data on unrelated SCT for adult patients with high-risk ALL. Many studies include both paediatric and adult patients, or provide combined data from ALL and acute myeloid leukaemia (AML) patients. Moreover, the follow-up of the reported series is highly variable, and the definition of high-risk criteria varies from one study to another. The reported disease-free survival (DFS) for adult ALL patients ranges from 30 to $70 \%$, and leukaemia relapse (14-47\%) is an important cause of treatment failure. Despite great improvements in recent years, transplant-related mortality (TRM) from unrelated SCT (USCT) remains unacceptably high (29-36\%). The human leukocyte antigen (HLA) disparity in the unrelated donor setting with a high incidence of graft-versus-host disease (GVHD) and delayed immunological reconstitution with a high incidence of infectious events in the unrelated cord blood SCT are the most important causes of morbidity and mortality in unrelated transplants. Disease status at transplant and the presence of acute and/or chronic GVHD are the most important factors determining relapse in high-risk ALL adult patients undergoing USCT.
\end{abstract}

\section{Keywords}

Acute lymphoblastic leukaemia, allogeneic haematopoietic progenitor transplant, unrelated cord-blood transplant, adult, unrelated donor haematopoietic stem cell transplant

Disclosure: The authors have no conflicts of interest to declare.

Received: 22 May 2009 Accepted: 26 June 2009

Correspondence: Christelle Ferrà, Department of Clinical Haematology, Institut Català d'Oncologia, Hospital Germans Trias i Pujol, Universitat Autònoma de Barcelona,

C/ Canyet s/n, 08916-Badalona, Spain. E: cferra@iconcologia.net

The outcome of adults with high-risk acute lymphoblastic leukaemia (ALL) features at diagnosis, slow responders or those with recurrent disease is poor with standard chemotherapy. Autologous stem cell transplantation (ASCT) has not demonstrated a clear advantage over chemotherapy for ALL patients in complete remission due to the high relapse rate, ${ }^{1-4}$ and allogeneic SCT (alloSCT) - even if associated with a higher transplant-related mortality (TRM) - remains the best therapeutic option for such high-risk ALL patients. ${ }^{5-9}$ In standard-risk ALL, the role of alloSCT remains uncertain in patients in first complete remission (CR). However, the UKALL/XII/Eastern Cooperative Oncology Group (ECOG) 2993 and the Dutch-Belgian Cooperative Trial Group for Hematology Oncology (HOVON)-18 ALL/HOVON-37 ALL studies have recently shown a survival advantage for those patients receiving a sibling-matched alloSCT. ${ }^{2,10}$ The expected disease-free survival (DFS) in high-risk adult patients is between 30 and $40 \%,{ }^{11}$ and in most centres such patients are considered for an alternative donor SCT if a matched-sibling donor is not available, which reportedly occurs in about two-thirds of patients. ${ }^{12-14}$ Alternative haematopoietic sources can be partially human leukocyte antigen (HLA)-matched family donors, unrelated donors (UDS) or unrelated cord blood units, the latter having emerged as an option for unrelated SCT (USCT) even in adult patients. ${ }^{15-20}$ Despite some groups having reported a similar outcome for related and unrelated SCT in adult ALL patients, ${ }^{14,21-24}$ there seems to be a trend towards a poorer outcome in USCT due to a higher TRM. ${ }^{25}$ However, long-term results of adult patients receiving an alloSCT from an alternative source are scarce. The best choice of unrelated progenitor source and the best timing for the USCT remain matters of concern for many haematologists, especially in adult patients.

\section{Indication for Unrelated Stem Cell Transplantation in Adult Acute Lymphoblastic Leukaemia}

High-risk criteria in ALL patients include disease stage beyond the first $\mathrm{CR}$ and patients with first remission if they have poor-risk cytogenetics $(t[9 ; 22], t[4 ; 11], t[1 ; 19]$, complex karyotype [more than four cytogenetic abnormalities] and low hypodiploidy/near triploidy), a slow response to induction chemotherapy (more than four weeks to achieve the first CR), failure to achieve complete CR after one induction course, leukocytosis at diagnosis ( $>30 \times 10^{9} / \mathrm{I}$ in B-precursor ALL or $>100 \times 10^{9} / \mathrm{I}$ in T-cell ALL [T-ALL]) or age $>35$ years. Moreover, a significant level of minimal residual disease (MRD) has recently been associated with a poor outcome despite good prognostic features at diagnosis and the patients being in morphological remission. ${ }^{26-28}$ Identification of biologically distinct subsets of ALL through cytogenetic, molecular and gene expression studies, as well as investigation of MRD and host pharmacogenomics, offers promising avenues of research. Integration of molecular tools into clinical practice will ultimately allow more precise risk stratification and individualised treatment planning. ${ }^{29}$ In a recent report, USCT was clearly 
proved to be superior to conventional chemotherapy in the pre-imatinib era for patients with Philadelphia-chromosome-positive (Phi+) ALL lacking a matched related donor. ${ }^{25}$ The phase of the disease at transplant is one of the most important factors influencing relapse in the unrelated transplant setting for both USCT and unrelated cord blood SCT. ${ }^{12,13,2,30,31}$ Advanced disease status is associated not only with a higher relapse rate but also with a higher TRM. ${ }^{12-14}$ The follow-up of 609 adult patients after relapse of ALL in the UKALL12/ECOG 2993 study revealed that only a very highly selected subgroup of patients were able to receive SCT after relapse, resulting in a superior overall survival (OS) (16\% for matched unrelated and $23 \%$ for sibling allograft SCT) than those receiving chemotherapy alone (4\%). ${ }^{32}$ The grim prognosis of adult patients with high-risk ALL after relapse justifies considering alternative donor transplants in first CR if a sibling donor is lacking. The prevention of relapse remains the most important goal for long-term survival in ALL patients. Moreover, the detection of residual disease during the posttransplant period may be useful to diagnose recurrent disease early, allowing early therapeutic interventions. ${ }^{33}$

\section{Stem Cell Source}

\section{Unrelated Donor Stem Cell Transplant}

For many years, bone marrow has been the stem cell source of choice for unrelated transplants. However, the mobilised peripheral blood stem cell (PBSC) has been widely adopted by many centres as the preferred unrelated stem cell source. Some data have pointed out a worse prognosis for patients receiving PBSC versus bone marrow graft in the unrelated setting for $\mathrm{ALL}^{34,35}$ due to a higher incidence of chronic graftversus-host disease (GVHD) in former patients. Some groups have explored T-cell depletion of unrelated PBSC $^{36}$ or bone marrow ${ }^{12}$ without showing a clear advantage in survival for T-cell-depleted grafts Cornelissen et al. ${ }^{12}$ reported their experience with unrelated bone marrow transplant provided by the National Marrow Donor Program (NMDP) collection centres for transplant in adult patients with ALL, and concluded that the main factors for a better DFS were first CR at SCT, absence of HLA-A, -B or DRB1 mismatch, negative cytomegalovirus (CMV) serology and a shorter interval from diagnosis to transplantation. For patients in first $\mathrm{CR}$, the OS ( $95 \%$ confidence interval $[\mathrm{CI}]$ ), relapse rate and TRM at two years were $40 \%(13 \%), 6 \%(7 \%)$ and $54 \%(13 \%)$ respectively. These data included patients from an early period (1988-1999), but more recent reports incorporating high-resolution typing HLA methods for HLA-A, $-B$ and $-C$ have shown better expected survival in the USCT setting with a decreased TRM. ${ }^{14,37} A$ large experience with 169 adult patients with Philadelphia-chromosome-negative (Phi-) ALL in first CR reported a 38\% DFS probability, with a 20\% TRM and a 42\% relapse rate at five years. The most important factors determining poor survival besides the degree of HLA mismatch and T-cell depletion were a white blood cell count $>100 \times 10^{9} / \mathrm{l}$, more than eight weeks to attain CR and CMV seropositivity. The analysis of 1,874 unrelated bone marrow transplantations under the auspices of the NMDP showed that lowresolution mismatches have a more severe impact on survival than mismatches detectable only with high-resolution typing techniques. ${ }^{38}$ Moreover, the impact of a mismatch at a particular locus depended on the total number of mismatches between donor and recipient ${ }^{39}$ with the T-cell undepleted grafts. The adverse impact of mismatch on unrelated donor stem cell transplant (UD-SCT) outcome was especially marked in patients without advanced malignancy.

\section{Unrelated Cord Blood Stem Cell Transplant}

Unrelated cord blood was initially introduced as an alternative source for SCT for paediatric patients, but more recently it has been considered for adult patients. ${ }^{17}$ Initial experiences with unrelated cord blood stem cell transplant (UCB-SCT) showed the importance of receptor age, the cell dose infused and the degree of HLA disparity in transplant outcome. ${ }^{40}$ Cord blood progenitors are more permissive with HLA disparities, and it is standard practice to allow zero to two HLA mismatches using lowresolution typing methods for HLA-A and $-B$ and high-resolution molecular typing for HLA-DRB1. In contrast, recommendation for unrelated bone marrow or PBSC transplants is more restrictive and considers zero to one mismatch using high-resolution molecular typing of eight or 10 allelles (HLA-A, -B, -C, -DRB1, -DP). The use of highresolution HLA typing by sequencing for HLA-A, $-B,-C$ and $-D Q$ has shown that the degree of mismatching in UCB-SCT is even higher than expected. However, it does not seem to have a significant impact on the long-term clinical outcome in the UCB-SCT setting. ${ }^{41}$

\section{Comparison of Outcome Between Unrelated Donor Transplant and Unrelated Cord Blood Transplant}

Many studies have described the outcome of UCB-SCT and compared the results with those from UD-SCT. In most studies comparing the two sources, the proportion of patients with more advanced disease or with poor-prognosis leukaemia was higher in the UCB-SCT group. Moreover, some studies included both AML and ALL or a variable proportion of paediatric patients. Finally, the OS, DFS and TRM were estimated at different periods of time (one to five years or more) and a short period follow-up underestimated late TRM (see Table 1). Most comparative studies of UCB-SCT versus bone marrow SCT for leukaemia from UDS have shown similar outcomes. ${ }^{18-20}$ Initial comparisons between UCB-SCT and UD-SCT (including only bone marrow SCT) showed that patients receiving an UCB-SCT had a delayed neutrophil and platelet engraftment and a lower incidence of acute GVHD, in spite of a greater HLA mismatch between the patient and the graft. ${ }^{18,19}$ However, the survival rate was similar when a comparison of procedures was performed at an early stage for transplants with cord blood progenitors in adult patients. Three major studies have compared the outcome of paediatric patients with ALL after USCT, focusing on the haematopoietic stem cell source.42-44 In paediatric patients, a better outcome for patients receiving a fully matched UD bone marrow transplant has been reported, and this was confirmed by some groups in an adult population. ${ }^{19}$ In terms of adult patients, Atsuta et al. ${ }^{45}$ carried out a large study using the Japanese registries to explore the impact of stem cell source (bone marrow or umbilical cord) for adult patients with acute leukaemia, making a disease-specific comparison. In the ALL group, there were no differences in terms of TRM, OS or DFS when eight out of eight matched bone marrow or UCB were compared. There was a trend towards a higher cumulative incidence of relapse in UCB recipients. As expected, UCB-SCT was associated with a lower incidence of chronic (especially extensive) and acute GVHD. The recurrence of the primary disease was the leading cause of death for high-risk ALL patients. Other studies did not find differences in relapse rate when UCB-SCT and UD-SCT were compared. ${ }^{18-20,45}$

The disadvantages of using UCB as a haematopoietic source are the limited number of stem cells in the unit, the impossibility of performing cellular therapy with lymphocytes belonging to the donor, the delayed haematological recovery and the delayed immune reconstitution. However, a higher infectious vulnerability may be compensated by a lower risk of GVHD. ${ }^{18,46}$ Due to slower haematopoietic and immune reconstitutions after UCB-SCT, severe infections are more frequent after UCB-SCT than after non-T-cell-depleted progenitors in UD-SCT, 
Table 1: Relevant Studies on Outcome of Adult Acute Lymphoblastic Leukaemia Patients with Unrelated Stem Cell Transplantation

\begin{tabular}{|c|c|c|c|c|c|c|c|c|c|c|c|}
\hline & $n$ & Age & Donor & $\begin{array}{l}\text { Stem Cell } \\
\text { Source }\end{array}$ & ALL & $\begin{array}{l}\text { GvHD } \\
\text { Prophylaxis }\end{array}$ & $\begin{array}{l}\text { aGvHD } \\
>\| l(\%)\end{array}$ & cGvHD (\%) & TRM (\%) & RR (\%) & $\begin{array}{l}\text { DFS (\%) } \\
\text { (years) }\end{array}$ \\
\hline Sierra, $1997^{31}$ & 174 & $\begin{array}{l}\text { Paediatric } \\
\text { and adult }\end{array}$ & Unrelated & $\mathrm{BM}$ & 91 (52\%) & $\mathrm{CSA}+\mathrm{MTX}$ & 82 & 52 (extensive) & 39 & 41 & $19(6)$ \\
\hline $\begin{array}{l}\text { Rubenstein, } \\
1998^{40}\end{array}$ & 562 & $(0-58)$ & Unrelated & USCT & 177 (47\%) & $\begin{array}{l}\text { Several } \\
\text { schedules }\end{array}$ & 42 & 25 & - & 24 & - \\
\hline $\begin{array}{l}\text { Bornhäuser, } \\
2000^{36}\end{array}$ & 79 & $(4-58)$ & Unrelated & PBSC & 10 (13\%) & $\begin{array}{l}\text { Several } \\
\text { schedules }\end{array}$ & 47 & 27 & - & $38-8$ & $47(1)$ \\
\hline $\begin{array}{l}\text { Cornelissen, } \\
2001^{12}\end{array}$ & 127 & $(>17)$ & Unrelated & BM & 127 (100\%) & $\begin{array}{l}\text { Several } \\
\text { schedules }\end{array}$ & 50 & 48 (extensive) & - & 19 & $\begin{array}{l}40-32 \\
(2)\end{array}$ \\
\hline Sanz, $2001^{17}$ & 22 & $18-46$ & Unrelated & CB & $6(27 \%)$ & CSA + PDN & 32 & 40 (extensive) & 43 & - & $53(1)$ \\
\hline Rocha, $2004^{18}$ & 682 & $15-59$ & Unrelated & $\begin{array}{l}\mathrm{BM} \\
\mathrm{CB}\end{array}$ & $320(47 \%)$ & $\begin{array}{l}\text { CSA - MTX** } \\
\text { CSA - PDN* }\end{array}$ & $\begin{array}{l}39 \\
26\end{array}$ & $\begin{array}{l}46 \\
30\end{array}$ & $\begin{array}{l}38 \\
44\end{array}$ & $\begin{array}{l}23 \\
23\end{array}$ & $\begin{array}{l}38(2) \\
33(2)\end{array}$ \\
\hline $\begin{array}{l}\text { Laughlin, } \\
2004^{19}\end{array}$ & 600 & $16-60$ & Unrelated & $\begin{array}{l}\text { Matched BM } \\
\text { mmBM } \\
\text { CB }\end{array}$ & 144 (24\%) & $\begin{array}{l}\text { Several } \\
\text { schedules }\end{array}$ & $\begin{array}{l}48 \\
52 \\
41\end{array}$ & $\begin{array}{l}35 \\
40 \\
51\end{array}$ & $\begin{array}{l}46 \\
65 \\
63\end{array}$ & $\begin{array}{l}23 \\
14 \\
17\end{array}$ & $\begin{array}{l}33(3) \\
19(3) \\
23(3)\end{array}$ \\
\hline $\begin{array}{l}\text { Takahashi, } \\
2004^{20}\end{array}$ & 113 & $16-53$ & Unrelated & $\begin{array}{l}\text { CB } \\
\text { BM }\end{array}$ & $23(20 \%)$ & CSA + MTX & $\begin{array}{l}6 \text { (III-IV) } \\
27(\text { III-IV) }\end{array}$ & $\begin{array}{l}24 \text { (extensive) } \\
40 \text { (extensive) }\end{array}$ & $\begin{array}{l}9 \\
29\end{array}$ & $\begin{array}{l}16 \\
25\end{array}$ & $\begin{array}{l}74(2) \\
44(2)\end{array}$ \\
\hline Kiehl, 2004 ${ }^{14}$ & 221 & $17-62$ & $\begin{array}{l}\text { Related/ } \\
\text { unrelated }\end{array}$ & PBSC, BM & 221 (100\%) & $\mathrm{CSA}+\mathrm{MTX}$ & 30 & - & $\begin{array}{l}43 \\
50\end{array}$ & - & $29(3)$ \\
\hline Barker, $2005^{50}$ & 23 & $13-53$ & Unrelated & $\mathrm{CB} \times 2$ & 8 (35\%) & $\begin{array}{l}\text { Several } \\
\text { schedules }\end{array}$ & 65 & 25 & 22 & - & $57(1)$ \\
\hline Magro, $2006^{53}$ & 27 & $16-60$ & Unrelated & CB & 14 (52\%) & $\mathrm{CSA}+\mathrm{PDN}$ & $74(\geq 1)$ & 20 (limited) & 30 & 20 & $56(4)$ \\
\hline Chim, $2007^{13}$ & 108 & $15-56$ & $\begin{array}{l}\text { Related/ } \\
\text { unrelated }\end{array}$ & BM & 108 (100\%) & $\mathrm{CSA}+\mathrm{MTX}$ & $\begin{array}{l}32 \\
52\end{array}$ & - & $\begin{array}{l}15 \\
17\end{array}$ & $\begin{array}{l}64 \\
30\end{array}$ & $\begin{array}{l}41(15) \\
66(15)\end{array}$ \\
\hline Lee, $2007^{22}$ & 201 & $15-52$ & $\begin{array}{l}\text { Related/ } \\
\text { Unrelated }\end{array}$ & BM/PBSC & 201 (100\%) & $\begin{array}{l}\text { CSA/FK506 } \\
+ \text { MTX }\end{array}$ & $\begin{array}{l}41 \\
47\end{array}$ & $\begin{array}{l}50 \\
60\end{array}$ & $\begin{array}{l}21 \\
29\end{array}$ & $\begin{array}{l}36 \\
38\end{array}$ & $\begin{array}{l}50(5) \\
43(5)\end{array}$ \\
\hline Bishop, $2007^{1}$ & 260 & $>18$ & $\begin{array}{l}\text { Autologous/ } \\
\text { unrelated }\end{array}$ & BM & $\begin{array}{l}101(100 \%) \\
159(100 \%)\end{array}$ & $\begin{array}{l}\text { Several } \\
\text { schedules }\end{array}$ & ND & - & $\begin{array}{l}9 \\
45\end{array}$ & $\begin{array}{l}58 \\
21\end{array}$ & $\begin{array}{l}29(5) \\
33(5)\end{array}$ \\
\hline Marks, $2008^{37}$ & 169 & $16-59$ & Unrelated & PBSC/BM & 169 (100\%) & $\begin{array}{l}\text { Several } \\
\text { schedules }\end{array}$ & 50 & $38-43$ & $36-41$ & $15-20$ & $38(5)$ \\
\hline Atsuta, $2009^{45}$ & 336 & $16-59$ & Unrelated & $\begin{array}{l}\mathrm{BM} \\
\mathrm{CB}\end{array}$ & $\begin{array}{l}336(100 \%, \\
\left.28 \% \mathrm{Phi}^{+}\right)\end{array}$ & $\begin{array}{l}\text { Several } \\
\text { schedules }\end{array}$ & $\begin{array}{l}42 \\
28\end{array}$ & $\begin{array}{l}30 \\
27\end{array}$ & $\begin{array}{l}24 \\
25\end{array}$ & $\begin{array}{l}24 \\
31\end{array}$ & $\begin{array}{l}51(2) \\
45(2)\end{array}$ \\
\hline Ringdén, $2009^{24}$ & 4,099 & $>18$ & $\begin{array}{l}\text { Related/ } \\
\text { unrelated }\end{array}$ & PBSC/BM & 672 (16\%) & $\begin{array}{l}\text { Several } \\
\text { schedules }\end{array}$ & $\begin{array}{l}34 \\
52\end{array}$ & $\begin{array}{l}42 \\
49\end{array}$ & $\begin{array}{l}31-41 \\
40-48\end{array}$ & $\begin{array}{l}23-52 \\
15-48\end{array}$ & $\begin{array}{l}46-10(5) \\
42-5(5)\end{array}$ \\
\hline
\end{tabular}

$*$ In $70 \%$ of cases; **/n $>95 \%$ of cases.

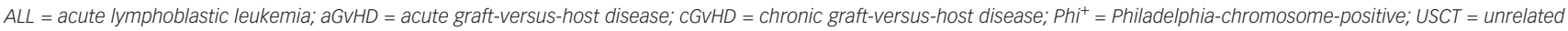
stem cell transplantation; $B M=$ bone marrow; $C B=$ cord blood; $\mathrm{mmBM}=$ mismatched bone marrow; $T$-DBM = T-cell-depleted bone marrow; $P D N=$ prednisone; $N D=$ not declared;

PBSC = peripheral blood stem cell; CSA = cyclosporine $A ; M T X=$ methotrexate; FK506 = tacrolimus

especially within 100 days after transplantation. ${ }^{19,47,48}$ Parody et al. ${ }^{48}$ extensively compared the infectious events in UCB-SCT and UD-SCT, and concluded that UCB-SCT recipients had a similar risk of death due to infection if an accurate selection of the cord blood unit was performed. With a median follow-up of three years, UCB-SCT recipients had a higher risk of developing any severe infection (85 versus 69\% in bone marrow/peripheral blood SCT recipients). However, at three years the risks of severe bacterial infection or other infections were similar in the UCB-SCT and UD-SCT. In addition, the 100-day and three-year incidences of infection-related mortality did not differ among groups.

In contrast to the adult setting, UCB-SCT seems to present a similar risk of serious infections than unmanipulated bone marrow in the paediatric population. ${ }^{49} \mathrm{~A}$ higher stem cell dose has shown to improve the outcome of acute leukaemia patients receiving SCT with progenitors from unrelated bone marrow (nucleated cells [NC] $\left.>3.65 \times 10^{8} / \mathrm{kg}\right)^{31}$ or umbilical cord blood (NC $>2 \times 10^{7} / \mathrm{kg}$ ). ${ }^{17}$ In contrast, in UCB-SCT, the importance of an HLA match has been less evident in many reports than that of cell dose. ${ }^{46}$ The HLA disparity will be only partially compensated by the progenitor cellular dose, $18,19,49$ and in some studies may be associated with a lower risk of leukaemia relapse. However, in UCB-SCT, even if the procedure is not so greatly compromised by HLA disparity, this will also be associated with a poorer outcome due to a higher risk of GVHD and TRM without any survival advantage. $18,19,31,38,47$

In most studies, a favourable disease status at transplant was the most important factor affecting outcome, rather than the type of stem cell source or donor type in patients with ALL. ${ }^{18-20,30,33,45,50,51}$ In high-risk ALL patients in first CR without a fully compatible donor, transplant from a donor with an acceptable degree of mismatch or from UCB may allow early and effective treatment, thereby avoiding the risk of disease progression during a prolonged search for a fully matched donor. Newer strategies to decrease TRM in UCB-HSCT, such as the thirdparty infusion, ${ }^{52}$ infusion of two partially HLA-matched $U_{C B}{ }^{53}$ or intrabone UCB administration, ${ }^{54,55}$ could be explored in the future. In the UD-HSCT setting, the generalised high-resolution typing methods ${ }^{38}$ and more efficient transmission of data from the donor registries will in the future allow to improve the clinical outcome of patients with a highrisk ALL who lack a sibling donor. 


\section{Conditioning Therapy}

Traditionally, conditioning therapy including total body irradiation (TBI) has been associated with better DFS for ALL patients, ${ }^{14,56}$ especially in children. ${ }^{57}$ Busulfan-containing regimens have been associated with a higher TRM (basically hepatic sinusoidal obstructive syndrome and haemorrhagic cystitis). ${ }^{58}$ The higher relapse rate associated with chemotherapy conditioning has not been confirmed by all groups. There are no randomised studies comparing different conditioning therapies specifically for ALL. Some comparative studies included only a variable proportion of ALL patients and most were performed in the matched-sibling setting. Moreover, none of these comparative studies performed busulfan adjustment based on the drug plasma levels. Nonmyeloablative conditioning regimens allow transplantation to be performed in patients who are not candidates for myeloablative therapies due to advanced age, co-morbidities or a previous myeloablative SCT. With this approach a graft-versus-leukaemia (GVL) effect may be obtained with acceptable toxicity in the related and unrelated settings. ${ }^{52,59,60}$ The high incidence of disease relapse remains the main drawback of such an approach. Disease status at transplant and the presence of chronic GVHD are other main factors influencing relapse in this setting. However, for adults with ALL in first CR, reducedintensity conditioning (RIC) allografting results in a promising DFS with acceptable TRM. In some groups, SCT with RIC has been followed by a double or multiple graft for UCB-SCT, a procedure that seems to be associated with a slightly higher incidence of GVHD and a possible improvement of the GVL effect. ${ }^{61}$ In vivo T-cell depletion is the most effective method for preventing GVHD after alloSCT, and in spite of a delayed immunological reconstitution this effect could decrease the TRM in USCT. ${ }^{62}$ In addition, the T-cell depletion of the graft has been associated with a higher incidence of CMV and fungal infection in the unrelated bone marrow setting, and as thymoglobulin is commonly given as conditioning therapy for UCB-SCT patients, this could contribute to a high incidence of infections in UCB-SCT. On the other hand, as T-cell depletion could also contribute to relapse, this procedure is not routinely performed in high-risk ALL patients.

\section{Graft-versus-leukaemia Effect}

In ALL, the antileukaemic activity of GVHD has been traditionally considered weaker than for other haematological diseases. However, many authors ${ }^{12,22,24,61-64}$ have demonstrated the antileukaemic effect of chronic GVHD, either in children ${ }^{65,66}$ or in adult patients receiving a related or especially an USCT, either with a myeloablative or RIC regimen. ${ }^{58}$ The reduced relapse rate is hampered by an increase in the non-relapse mortality and morbidity in long-term survivors, with severely impaired quality of life for patients presenting with the extensive form of the disease. Consequently, the GVL effect has been mostly evident in the limited type of chronic GVHD. This GVL effect of chronic GVHD has been pointed out as stronger for ALL patients with translocations (including $\left.\mathrm{Phi}^{+} \mathrm{ALL}\right)^{22,64}$ or normal diploid cytogenetics than for patients with deletions or numeric abnormalities. ${ }^{22}$ The presence of acute GVHD also had a positive impact in decreasing the relapse rate, ${ }^{14,25,33}$ but it is associated with a higher TRM and a decreased survival if it is severe. ${ }^{13,14}$ As the disease status at transplant and the presence of chronic GVHD are the main factors influencing relapse in adult patients with high-risk ALL after an unrelated transplant, ${ }^{22}$ the lower incidence of GVHD found in UCB-SCT could justify the trend for a higher relapse rate in patients receiving unrelated cord blood as the source of haematopoietic stem cells.

\section{Conclusions}

An alternative donor SCT should be considered for poor-prognosis adult ALL patients in first CR without a sibling donor. However, all unrelated transplant modalities are associated with high TRM. The disease status at transplant and the presence of GVHD are the main factors influencing relapse in adult patients with high-risk ALL after an unrelated transplant. A clear recommendation about which is the best conditioning therapy or even the best unrelated source does not exist. The particularities of patients, progenitor compatibility and cellularity (if unrelated cord blood progenitors) should be carefully considered prior to transplant. Finally, the time interval to obtain the unrelated haematopoietic progenitors should also be taken into account in the selection process.

Christelle Ferrà is an Attending Physician in the Haematology Department at the Catalan Institute of Oncology, University Hospital Germans Trias i Pujol in Badalona. She is a member of the Spanish Society of Hematology and the European Group for Blood and Marrow Transplantation. Dr Ferrà was licensed in medicine in 1988 at the Universitat Autònoma de Barcelona and became a specialist in haematology in 1992 She received her doctorate in medicine in 1996.

Josep-Maria Ribera is Chief of the Haematology Department and Director of the Stem Cell Transplantation Unit at the Catalan Institute of Oncology, University Hospital Germans Trias i Pujol in Badalona, and a Profesor of Medicine-Haematology at the Autonomous University of Barcelona. Dr Ribera is also Chairman of the trials of acute lymphoblastic leukaemia in the PETHEMA (Programa de Estudio y Tratamiento de las Hemopatías Malignas) Group of the Spanish Society of Hematology.
1. Bishop MR, Logan BR, Gandham S, et al., Long-term outcomes of adults with acute lymphoblastic leukemia after autologous or unrelated donor bone marrow transplantation: a comparative analysis by the National Marrow Donor Program and Center for International Blood and Marrow Transplant Research, Bone Marrow Transplant, 2007:41:635-42.

2. Goldstone $\mathrm{AH}$, Richards $\mathrm{SM}$, Lazarus $\mathrm{HM}$, et al., In adults with standard-risk acute lymphoblastic leukemia, the greatest benefit is achieved from a matched sibling allogeneic transplantation in first complete remission, and an autologous transplantation is less effective than conventional consolidation/mainte-nance chemotherapy in all patients: final results of the International ALL Trial (MRC UKALL XII/ECOG E2993), Blood, 2008;111:1827-33.

3. Ribera JM, Oriol A, Bethencourt $\mathrm{C}$, et al., Comparison of intensive chemotherapy, allogeneic or autologous stem cell transplantation as post-remission treatment for adult patients with high-risk acute lymphoblastic leukemia. Results of the PETHEMA ALL-93 trial, Haematologica, 2005; 90:1346-56.

4. Yanada M, Matsuo K, Suzuki T, Naoe T, Allogeneic hematopoietic stem cell transplantation as part of postremission therapy improves survival for adult patients with high-risk acute lymphoblastic leukemia: a metaanalysis, Cancer, 2006;106:2657-63

5. Hunault M, Harousseau JL, Delain M, et al., Better outcome of adult acute lymphoblastic leukemia after early genoidentical allogeneic bone marrow transplantation (BMT) than after late high-dose therapy and autologous BMT: a GOELAMS trial, Blood, 2004;104:3028-37.

6. Thiebault A, Vernant JP, Degos L, et al., Adult acute lymphocytic leukemia study testing chemotherapy, and autologous and allogeneic transplantation. Follow-up reports of the French protocol LALA 87, Hematol Oncol Clin North Am, 2000:14:1353-66.

7. Thomas X, Boiron JM, Huguet F, et al., Outcome of treatment of adults with acute lymphoblastic leukemia: analysis of LAL-94 trial, J Clin Oncol, 2004:22:4075-86.

8. Hallböök H, Hägglund $H$, Stockelberg D, et al., Autologous and allogeneic stem cell transplantation in adult ALL: the Swedish Adult ALL Group experience, Bone Marrow Transplant, 2005;35:1141-8.

9. Marks DI, Aversa F, Lazarus HM, Alternative donor transplants for adult acute lymphoblastic leukaemia: a comparison of the three major options, Bone Marrow Transplant, 2006:38:467-75.

10. Cornelissen JJ, Van der Holt B, Verhoef GEG, et al., Myeloablative allogeneic versus autologous stem cell transplantation in adult patients with acute lymphoblastic leukemia in first remission: a prospective sibling donor versus no donor comparison, Blood, 2009;113:1375-82.

11. Hoelzer D, Göckbuget N. New approaches in acute lymphoblastic leukemia in adults. Where do we go?, Semin Oncol, 2000;27:540-59.

12. Cornelissen JJ, Carston M, Kollman C, et al., Unrelated marrow transplantation for adult patients with poor-risk acute lymphoblastic leukemia: strong graft-versus-leukemia effect and risk factors determining outcome, Blood, 2001;97:1572-7.

13. Chim CS, Lie AKW, Liang R, et al., Long-term results of allogeneic bone marrow transplantation for 108 adult patients with acute lymphoblastic leukemia: favourable outcome with BMT at first remission and HLA-matched related donor, Bone Marrow Transplant, 2007;40:339-47.

14. Kiehl MG, Kraut L, Schwerdfeger R, et al., Outcome of 
allogeneic hematopoietic stem-cell transplantation in adult patients with acute lymphoblastic leukemia: No difference in related compared with unrelated transplant in first complete remission, J Clin Oncol, 2004:22:2816-25.

15. Singhai $\mathrm{S}$, Henslee-Downey PJ, Powles R, et al, Haploidentical versus autologous hematopoietic stem cell transplantation in patients with acute leukemia beyond first remission, Bone Marrow Transplant, 2003;31:889-95

16. Ottinger HD, Ferencik S, Beelen DW, et al., Hematopoietic stem cell transplantation: contrasting the outcome of transplantations from HLA-identical sibling, partially HLAmismatched related donors, and HLA-matched unrelated donors, Blood, 2003:102:1131-7.

17. Sanz GF, Saavedra S, Planelles D, et al., Standarized, unrelated donor cord blood transplantation in adults with hematologic malignancies, Blood, 2001;98:2332-8.

18. Rocha V, Labopin M, Sanz G, et al., Transplants of umbilicalcord blood or bone marrow from unrelated donors in adults with acute leukaemia, N Eng J Med, 2004;351:2276-85.

19. Laughlin MJ, Eapen M, Rubinstein P, et al., Outcomes after transplantation of cord blood or bone marrow from unrelated donors in adults with leukaemia, N Eng J Med, 2004;351:2265-75

20. Takahashi S, Iseki T, Ooi J, et al., single-institute comparative analysis of unrelated bone marrow transplantation and cord blood transplantation for adult patients with hematologic malignancies, Blood, 2004;104: 3813-20

21. Takahashi S, Ooi J,T Tomonari A, et al., Comparative singleinstitute analysis of cord blood transplantation from unrelated donors with bone marrow or peripheral blood stem-cell transplantats from related donors in adult patients with hematologic malignancies after myeloablative conditioning regimen, Blood, 2007;109:1322-30

22. Lee S, Cho BS, Kim SY, et al., Allogeneic stem cell transplantation in first complete remission enhances graftversus leukemia effect in adults with acute lymphoblastic leukemia: Antileukemic activity of chronic graft-versus host disease, Biol Blood Marrow Transplant 2007:13:1083-94

23. Dahlke J, Kröger N, Zabelina T, et al., Comparable results in patients with acute lymphoblastic leukemia after related and unrelated stem cell transplantation, Bone Marrow Transplant, 2006;37:155-63.

24. Ringdén $\mathrm{O}$, Pavletic $\mathrm{SZ}$, Anassetti $\mathrm{C}$, et al., The graft-versus leukemia effect using matched unrelated donors is not superior to HLA-identical siblings for hematopoietic stem cell transplantation, Blood, 2009;113:3110-18.

25. Fielding $A K$, Rowe JM, Richards SM, et al., Prospective outcome data on 267 unselected adult patients with Philadelphia chromosome positive acute lymphoblastic leukaemia confirms superiority of allogeneic transplant over chemotherapy in the pre-imatinib era: Results from the international ALL trial MRC UKALLXI/ECOG2993, Blood, 2009;113(19):4489-96.

26. Mortuza FY, Papaioannou M, Moreira MI, et al., Minimal residual disease tests provide an independent predictor of clinical outcome in adult acute lymphoblastic leukemia, Clin Oncol, 2002;20:1094-1104.

27. Bruggermann M, Raff, Flohr T, et al., Clinical significance of minimal residual disease quantification in adult patients with standard-risk acute lymphoblastic leukemia, Blood, 2006:107:1116-23

28. Bassan R, Spinelli O, Oldani E, et al., Improved risk classification for risk-specific therapy based on the molecular study of minimal residual disease (MRD) in adult acute lymphoblastic leukemia (ALL), Blood, 2009; 113:4153-62.

29. Pui $\mathrm{CH}$, Schrappe M, Ribeiro RC, Niemeyer CM, Childhood and adolescent lymphoid and myeloid leukemia, Hematology Am Soc Hematol Educ Program, 2004;118-45.

30. Ferra C, Sanz J, Cámara R, et al., Predictive factors for relapse in adult patients with high-risk acute lymphoblastic leukemia submitted to na unrelated haematopoietic progenitor transplant, Bone Marrow Transplant, 2009;43(Suppl. 1):139a.

31. Sierra J, Storer B, Hansen JA, et al., Transplantation of marrow cells from unrelated donors for treatment of highrisk acute leukemia: the effect of leukemic burden, donor HLA-matching, and marrow cell dose, Blood, 2008;11:
4226-35.

32. Fielding AK, Richards SM, Chopra R, et al., Outcome of 609 adults after relapse of acute lymphoblastic leukemia (ALL); an MRC UKALL12/ECOG 2993 study, Blood, 2007;109: 944-50

33. Espérou H, Boiron JM, Cayuela JM, et al., A potential graftversus-leukemia effect after allogeneic hematopoietic stem cell transplantation for patients with Philadelphia chromosome-positive acute lymphoblastic leukemia: results from the French Bone Marrow Transplantation Society, Bone Marrow Transplant, 2003;31:909-18.

34. Garderet L, Labopin M, Gorin NC, et al., Patients with acute lymphoblastic leukaemia allografted with a matched unrelated donor may have a lower survival with a peripheral blood stem cell graft compared to bone marrow, Bone Marrow Transplant, 2003:31:23-9.

35. Eapen M, Rubinstein P, Zhang MJ, et al., Outcome of transplantation of unrelated donor umbilical cord blood and bone marrow in children with acute leukaemia: a comparison study, Lancet, 2007:369:1947-54.

36. Bornhäuser M, Theuser C, Soucek S, et al., Allogeneic transplantation of G-CSF mobilized peripheral blood stem cell from unrelated donors: a retrospective analysis, Haematologica, 2000:85:839-47.

37. Marks DI, Pérez WS, He W, et al., Unrelated donor transplants in adult patients with Philadelphia-negative acute lymphoblastic leukemia in first complete remission, Blood, 2008;112:426-34.

38. Flomenberg N, Baxter-Lowe LA, Confer D, et al., Impact of HLA class I and class I| high-resolution on outcomes of unrelated donor bone marrow transplantation: HLA-C mismatching is associated with a strong adverse effect on transplantation outcome, Blood, 2004;104:1923-30.

39. Petersdorf EW, Anasetti C, Martin PJ, et al., Limits of HLA mismatching in unrelated hematopoietic cell transplantation, Blood,. 2004;104:2976-80.

40. Rubinstein $\mathrm{P}$, Carrier $\mathrm{C}$, Scaradavou A, et al., Outcomes among 562 recipients of placental-blood transplants from unrelated donors, N Engl J Med, 1998;339:1565-77.

41. Kögler G, Enczmann J, Rocha V, et al., High-resolution HLA typing by sequencing for HLA-A, - $B,-C$, -DR, -DQ in 122 unrelated cord blood/patient pair transplants hardly improves long-term clinical outcome, Bone Marrow Transplant 2005;36:1033-41

42. Barker J, Davies S, DeFor T, et al., Survival after transplantation of unrelated donor umbilical cord blood is comparable of that of human leukocyte antigen-matched unrelated donor bone marrow: results of a matched-pair analysis, Blood, 2001;97:2957-61.

43. Rocha V, Cornish J, Sievers EL, et al., Comparison outcomes of unrelated bone marrow and umbilical cord transplants in children with acute leukemia, Blood, 2001; 97:2962-71.

44. Eapen M, Logan BR, Confer DL, et al., Peripheral blood grafts from unrelated donors are associated with increased acute and chronic graft-versus-host disease without improved survival, Biol Blood Marrow Transplant, 2007;13:1461-8

45. Atsuta Y, Suzuki R, Nagamura-Inoue T, et al., Diseasespecific analyses of unrelated cord blood transplant compared with unrelated bone marrow transplant in adult patients with acute leukemia, Blood, 2009;113:1631-8.

46. Barker JN. Umbilical Cord Blood (UCB) Transplantation: An Alternative to the Use of Unrelated Volunteer Donors?, Hematology Am Soc Hematol Educ Program, 2007:2007:55-61.

47. Hamza NS, Lisgaris M, Yadavalli G, et al., Kinetics of myeloid and lymphocyte recovery and infectious complications after unrelated umbilical cord blood versus HLA-matched unrelated donor allogeneic transplantation in adults, $\mathrm{Br}$. Haematol, 2004:124:488-98.

48. Parody R, Martino R, Rovira M, et al., Severe infections after unrelated donor allogeneic hematopoietic stem cell transplantation in adults: comparison of cord blood transplantation with peripheral blood and bone marrow transplantation, Biol Blood Marrow Transplant, 2006:12:734-48.

49. Barker J, Hough RE, Van Burik JAH, et al., Serious infection after unrelated donor transplantation in 136 children: impact of stem cell source, Biol Blood Marrow Transplant 2005:11:362-70.

50. Barker J, Weisdorf DJ, DeFor TE, et al., Transplantation of
2 partially HLA-matched umbilical cord units to enhance engraftment in adults with hematological malignancy, Blood 2005;105:1343-7.

51. Bachanova V, Verneris MR, DeFor T, et al., Prolonged survival in adults with acute lymphoblastic leukemia after reduced-intensity conditioning with cord blood or sibling donor transplantation, Blood, 2009;113:2902-5.

52. Magro E, Regidor C, Cabrera R, et al., Early hematopoietic recovery after single unit unrelated cord blood transplantation in adults supported by co-infusion of mobilized stem cells from a third party donor, Haematologica, 2006;91:640-48

53. Barker J, Weisdorf DJ, DeFor TE, et al., Transplantation of 2 partially HLA-matched umbilical cord units to enhance engraftment in adults with hematologic malignancy, Blood 2005;105:1343-47.

54. Frassoni F, Gualandi F, Podestà M, et al., Direct intrabone ransplant of unrelated cord-blood cells in acute leukaemia: a phase I/II study, Lancet Oncol, 2008;9:831-9.

55. Brunstein CG, Barker JN, Weisdorf DJ, et al., Intra-BM injection to enhance engraftment after myeloablative umbilical cord blood transplantation with two partially HLA matched units, Bone Marrow Transplant, 2009 (Epub ahead of print).

56. Granados E, De La Camara R, Madero L, et al., ematopoietic cell transplantation in acute lymphoblastic leukaemia: better long-term event-free survival with conditioning regimens containing total body irradiation, Hematologica, 2000:85:1060-67.

57. Davies SM, Ramsay NKC, Klein JPK, et al., Comparison o preparative regimens in transplants for children with acute Iymphoblastic leukemia, J Clin Oncol, 2000;18:340-47.

58. Hartman AR, Williams SF, Dillon JJ, Survival, disease-free survival and adverse effects of conditioning for allogeneic bone marrow transplantation with busulfan/ cyclophosphamide vs total body irradiation: a metaanalysis, Bone Marrow Transplant, 1998:22:439-43.

59. Martino R, Giralt S, Caballero MD, et al., Allogeneic hematopoietic stem cell transplantation with reducedintensity conditioning in acute lymhpblastic leukemia: feasibility study, Haematologica, 2003;88:555-60.

60. Mohty M, Labopin M, Tabrizzi R, et al., Reduced intensity conditioning allogeneic stem cell transplantation for adult patients with acute lymphoblastic leukemia: a retrospective study from the European Group for Blood and Marrow Transplantation, Haematologica, 2008:93:303-6

61. Schoemans H, Theunissen K, Maertens J, et al., Adult umbilical cord blood transplantation: a comprehensive review, Bone Marrow Transplant, 2006;38:83-93.

62. Hale G, Jacobs P, Wood L, et al., CD52 antibodies for prevention of graft-versus-host disease and graft rejection following transplantation of allogeneic peripheral blood stem cells, Bone Marrow Transplant, 2000;26:69-76.

63. Zikos P, Van Lint MT, Lamparelli T, et al., Allogeneic hemopoietic stem cell transplantation for patients with high risk acute lymphoblastic leukemia: favorable impact of chronic graft-versus-host disease on survival and relapse Haematologica, 1998;83:896-903.

64. Grigg AP, Szer J, Beresford J, et al., Factors affecting the outcome of allogeneic bone marrow transplantation for adult patients with refractory or relapsed acute leukaemia Br J Haematol, 1999:107:409-18.

65. Nordlander A, Mattsson J, Ringdén O, et al., Graft-versushost disease is associated with a lower relapse incidence after hematopoietic stem cell transplantation in patients with acute lymphoblastic leukemia, Biol Blood Marrow Transplant, 2004:10:195-20.

66. Stirewalt DL, Guthrie KA, Beppu L, et al., Predictors of relapse and overall survival in Philadelphia chromosomepositive acute lymphoblastic leukemia after transplantation, Biol Blood Marrow Transplant, 2003;9:206-12.

67. Zecca M, Prete A, Rondelli R, et al., Chronic graft-versushost disease in children: incidence, risk factors, and important outcome, Blood, 2002;100:1192-1200.

68. Gassas A, Sung L, Saunders EF, Doyle J, Graft-versusleukemia effect in hematopoietic stem cell transplantation for pediatric acute lymphoblastic leukemia: significantly lower relapse rate in unrelated transplantations, Bone Marrow Transplant, 2007;40:951-5. 